\title{
The Effect of Prenatal Yoga on Birth Labor Duration and Pain: A Meta Analysis
}

\author{
Meida Siwi Riawati'), Uki Retno Budihastuti²), Hanung Prasetya3) \\ 1)Masters Program in Public Health, Universitas Sebelas Maret \\ 2)Department of Obstetrics and Gynecology, Dr. Moewardi Hospital, Surakarta \\ ${ }^{3)}$ Health Polytechnics, Ministry of Health Surakarta
}

\section{ABSTRACT}

Background: Increased psychological burden during pregnancy can cause problems with the quality of the fetus and cause complications in pregnancy. The lack of knowledge about labor pain management and the mother's perception of prolonged labor makes the mother experience an increase in the psychological burden during pregnancy. One alternative therapy needed in dealing with a happy pregnancy and minimal trauma delivery is to do prenatal yoga. The purpose of this study was to estimate the magnitude of the effect of prenatal yoga on the duration of labor and labor pain.

Subjects and Method: This study uses a systematic review and meta-analysis research design. The time of the selected test results is between 2005 to 2021 . The search for articles is carried out for 1 month. Research data was searched from databases: PubMed, Science Direct, Springer Link, Google Scholar, Chocrance Library. The inclusion criteria in this study were full text articles in English, the study design used a randomized controlled trial. Article searches were carried out using the PICO model. The population in this study were pregnant women, the intervention was in the form of prenatal yoga, comparison was without prenatal yoga, and the outcomes were labor duration and labor pain. Data processing is carried out using the Review Manager (RevMan 5.3 ) by calculating the standardized mean difference to determine the combined research model and form the final result of the metaanalysis.

Results: There are 9 articles in the study of the effect of prenatal yoga on the duration of labor and there are 5 articles on labor pain. The study showed that prenatal yoga significantly reduced labor duration $(\mathrm{SMD}=0.88 ; 86 \% \mathrm{CI}-1.31$ to $0.44 \mathrm{p}<0.001)$. Prenatal yoga can also reduce labor pain (SMD $=0.88 ; 77 \% \mathrm{CI}-1.44$ to -0.33 $\mathrm{p}=0.002)$.

Conclusion: Prenatal yoga can reduce labor duration and reduce labor pain.

Keywords: labor duration, labor pain, prenatal yoga, pregnancy

\section{Correspondence:}

Meida Siwi Riawati. Masters Program in Public Health. Universitas Sebelas Maret, Jl. Ir. Sutami 36A, Surakarta 57126, Central Java. Email: meida.siwi.r@gmail.com. Mobile: 087824093041.

\section{Cite this as:}

Riawati MS, Budihastuti UR, Prasetya H (2021). The Effect of Prenatal Yoga on Birth Labor Duration and Pain: A Meta Analysis. J Matern Child Health. 06(02): 327-337. https://doi.org/10.26911/thejmch.2021.06.03.07.

\section{BACKGROUND}

Physical and psychological changes in pregnant women can occur due to hormonal imbalances in the body of progesterone and estrogen which are female hormones that have been in the mother's body since the pregnancy process (Irianti et al., 2014).

Increased psychological burden on pregnant women can cause problems with the quality of the fetus and the emergence of complications that accompany the 
delivery process. Lack of knowledge about labor pain management, the mother's perception of prolonged labor or non-progressive labor makes the mother experience an increased psychological burden during pregnancy (Shindu, 2014).

According to several studies on labor pain, as many as 35\% experienced moderate labor pain, 30\% experienced severe labor and 20\% experienced extreme labor (Tounair, 2007 in Nelly, 2015). In 2017, around 810 women died from preventable pregnancy complications. Long labor is the cause of complications with an incidence of 69,000 or $2.8 \%$ of deaths (WHO, 2018).

One alternative therapy needed in dealing with a happy pregnancy and minimal trauma and minimal complications is to do meditation/yoga (Jahdi et al., 2017). Prenatal yoga is a sport that can harmonize the body, mind, and spirit by building a strong posture and training muscles to be flexible and strong (Aflahiyah et al., 2020).

Prenatal yoga can be used to prepare the mother's psychological condition in facing childbirth. Prenatal yoga will provide benefits to the biomotor component of the muscles being trained, it can also increase cardiorespiratory endurance by increasing oxygen consumption. Prenatal yoga will have a positive effect on cervical dilatation and coordinated uterine activity during labor (Bussing et al., 2012).

Research on prenatal yoga conducted by Chuntharapat (2008) shows that women who do yoga will feel less labor pain than women who do not do prenatal yoga. Women who practice yoga are also reported to experience shorter deliveries (Chuntharapat et al., 2008).

This study is expected to estimate the magnitude of the effect of prenatal yoga on the duration of labor and labor pain.

\section{SUBJECTS AND METHOD}

\section{Study Design}

This research was conducted using a systematic review and meta-analysis with PRISMA flow diagram guidelines. Search articles using databases: PubMed, Science Direct, Springer Link, and Google Scholar and are carried out within 1 month. Search keywords used: "Yoga" OR "Prenatal Yoga" AND "Labor Pain" OR "Delivery Pain" AND "Duration Labor "OR Stage of Labor" AND "Randomized Control Trial".

\section{Inclusion Criteria}

The author developed the inclusion criteria, namely full text English articles with a Randomized Controlled Trial study design. The research subjects were pregnant women and the outcomes analyzed were labor duration and labor pain.

\section{Exclusion Criteria}

The exclusion criteria in this study were non-randomized controlled trial studies, articles were not full text and published before 2005 .

\section{Operational Definition of Variables}

The search for articles was carried out by considering the eligibility criteria defined using the PICO model. The population in the study were pregnant women with prenatal yoga intervention, comparison did not do prenatal yoga, outcomes in the form of labor duration and labor pain

Duration of Labor is how long it takes for normal delivery, the instrument is a calculation with hours and a continuous measuring scale.

Labor pain is pain/ discomfort experienced by mothers in labor due to uterine contractions. The instruments are pain scale and continuous measuring scale.

Prenatal yoga is an exercise movement in pregnancy that aims to prepare pregnant women physically, mentally and spiritually. The instrument used is a published article. 
Riawati et al./ The Effect of Prenatal Yoga on Birth Labor Duration and Pain

\section{Instruments}

The study uses the PRISMA flow diagram guidelines and the assessment of the quality of research articles using the Critical Appraisal Checklist for RCT Study tools (CEBMa, 2014).

\section{Data Analysis}

The data in this study were analyzed using the RevMan 5.3 application, to calculate the effect size and heterogeneity of the study. The results of data processing are presented in the form of forest plots and funnel plots.

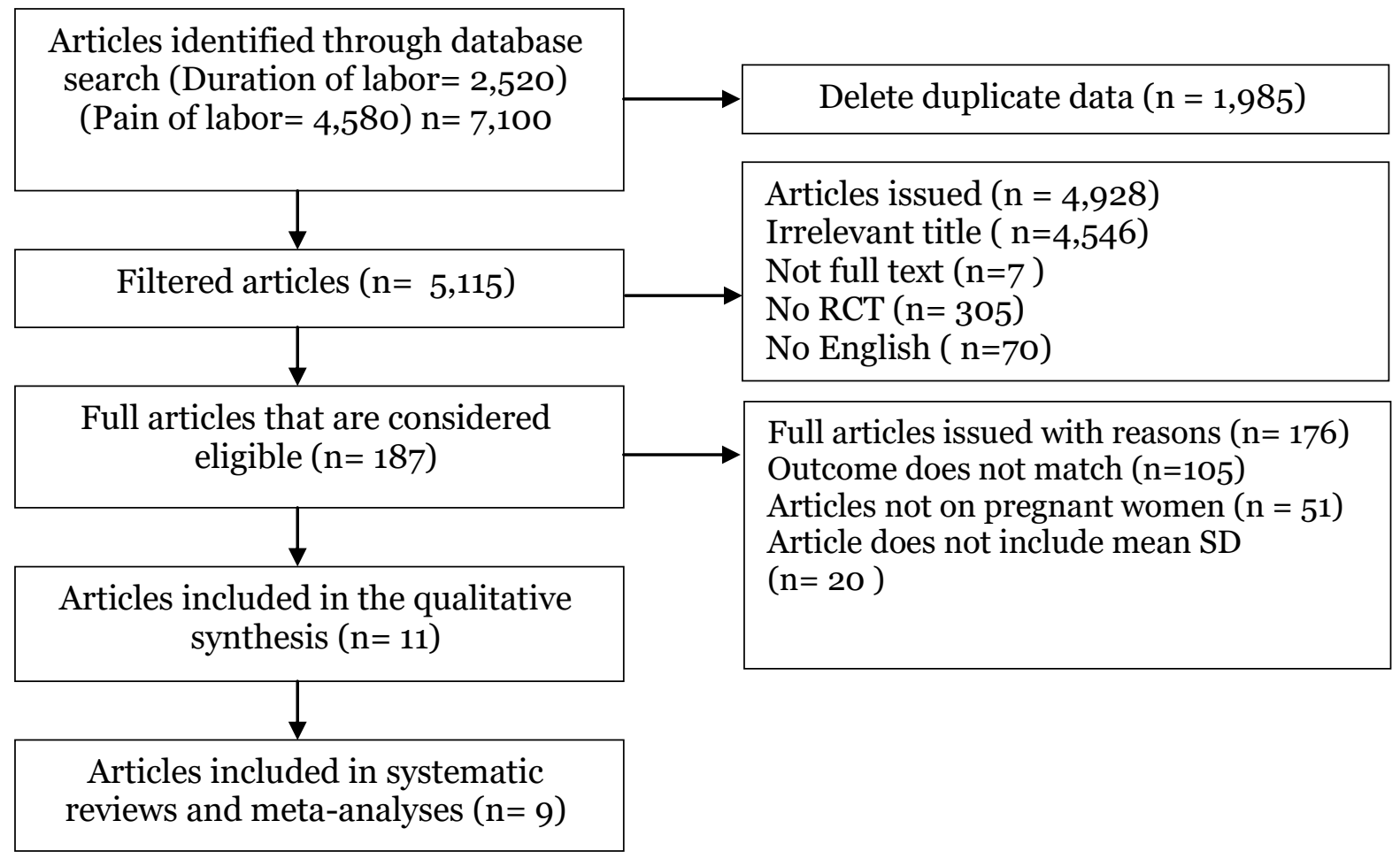

Figure 1. PRISMA Flowchart

\section{RESULTS}

The article review process using the PRISMA flow chart can be seen in Figure 1.

The total articles obtained were 9 articles.

Table 1. Research Quality Assessment of the Effect of Prenatal Yoga on Labor Duration

\begin{tabular}{|c|c|c|c|c|c|c|c|c|c|c|c|c|c|}
\hline \multirow{2}{*}{ Primary Study } & \multicolumn{12}{|c|}{ Criteria } & \multirow{2}{*}{ Total } \\
\hline & $\mathbf{1}$ & 2 & 3 & 4 & 5 & 6 & 7 & 8 & 9 & 10 & 11 & 12 & \\
\hline Bolanthakodi et al. (2018) & 1 & 1 & 1 & 1 & 1 & 1 & 1 & 1 & 1 & 1 & 1 & 1 & 12 \\
\hline Chuntharapat et al (2008) & 1 & 1 & 1 & 1 & 1 & 1 & 1 & 1 & 1 & 1 & 1 & 1 & 12 \\
\hline Jahdi et al.(2016) & 1 & 1 & 1 & 1 & 1 & 1 & 1 & 1 & 1 & 1 & 1 & 1 & 12 \\
\hline Karnasih (2018) & 1 & 1 & 1 & 1 & 1 & 1 & 1 & 1 & O & 0 & 1 & 1 & 10 \\
\hline Kumar et al. (2017) & 1 & 1 & 1 & 1 & 1 & 1 & 1 & 1 & 1 & $\mathrm{O}$ & 1 & 1 & 11 \\
\hline Levett et al. (2016) & 1 & 1 & 1 & 1 & 1 & $\mathrm{O}$ & 1 & 1 & 1 & 1 & 0 & 1 & 10 \\
\hline Mohyadin et al. (2019) & 1 & 1 & $\mathrm{O}$ & 1 & 1 & 1 & 1 & 1 & 1 & $\mathrm{O}$ & 1 & 1 & 10 \\
\hline Satyapriya et al. (2013) & 1 & 1 & 1 & 1 & 1 & $\mathrm{O}$ & 1 & 1 & 1 & 1 & 1 & 1 & 11 \\
\hline Yekefallah et al. (2021) & 1 & 1 & 1 & 1 & 1 & 1 & 1 & 1 & 1 & 1 & O & 1 & 11 \\
\hline
\end{tabular}

Note:

Answer $1=$ yes

Answer $\mathrm{O}=$ no
The distribution of the article is on 2 continents with details 8 from Asia and 1 from Australia. 
Riawati et al./ The Effect of Prenatal Yoga on Birth Labor Duration and Pain

Table 2. Research Quality Assessment of the Effect of Prenatal Yoga on Labor Pain

\begin{tabular}{lccccccccccccc}
\hline \multicolumn{1}{c}{ Primary Study } & \multicolumn{11}{c}{ Criteria } & \multirow{1}{*}{ Total } \\
\cline { 2 - 13 } & $\mathbf{1}$ & $\mathbf{2}$ & $\mathbf{3}$ & $\mathbf{4}$ & $\mathbf{5}$ & $\mathbf{6}$ & $\mathbf{7}$ & $\mathbf{8}$ & $\mathbf{9}$ & $\mathbf{1 0}$ & $\mathbf{1 1}$ & $\mathbf{1 2}$ & \\
\hline Bolanthakodi et al. (2018) & 1 & 1 & 1 & 1 & 1 & 1 & 1 & 1 & 1 & 1 & 1 & 1 & 12 \\
Chuntharapat et al. (2008) & 1 & 1 & 1 & 1 & 1 & 1 & 1 & 1 & 1 & 1 & 1 & 1 & 12 \\
Jahdi et al. (2016) & 1 & 1 & 1 & 1 & 1 & 1 & 1 & 1 & 1 & 1 & 1 & 1 & 12 \\
Karnasih (2018) & 1 & 1 & 1 & 1 & 1 & 1 & 1 & 1 & 0 & 0 & 1 & 1 & 10 \\
Mohyadin et al. (2019) & 1 & 1 & 0 & 1 & 1 & 1 & 1 & 1 & 1 & 0 & 1 & 1 & 10 \\
\hline
\end{tabular}

Note:

Answer $1=$ yes

Answer $0=$ no

Quality research in this study uses critical appraisal tools randomized controlled trial (RCT) published by (CEBMa (Center for Evidence-Based Medicine). The 12 questions used are as follows:

1. Does the research address clearly focused statements/problems?

2. Is the randomized controlled trial research method appropriate to answer the research question?

3. Were there enough subjects in the study to establish that the findings did not occur by chance?

4. Were subjects randomly allocated to the experimental and control groups? If not, could this be biased?

5. Were inclusion/exclusion criteria used?

6 . Were the two groups comparable at the start of the study?

7. Were objective and unbiased outcome criteria used?

8. Are objective and validated measurement methods used in measuring the results? If not, were the results judged by someone who was not aware of the group assignment (i.e. was the assessment blinded?)

9. Is effect size practically relevant?
10. How precise is the estimate of the effect? Is there a confidence interval?

11. Could there be confounding factors that have not been taken into account?

12. Are the results applicable to your research?

The researcher extracted data from the articles that had been obtained by making a simple table containing the author and year of publication, research title, research objectives, study design, research location, number of samples, interventions provided, and research results. www.summary source articles were identified from the results of the review and 9 articles were found that qualified as sources for meta-analysis research. Research related to the effect of prenatal yoga on the duration of labor comes from the Asian continent and the Australian continent, which consists of various countries including Indonesia, Iran, India, Thailand and Australia. An overview of each study can be seen in Table 3 .

Articles related to the effect of prenatal yoga on labor pain come from the Asian continent which consists of Indonesia, Iran, India, Thailand and Thailand. An overview of each study can be seen in Table 4 . 
Riawati et al./ The Effect of Prenatal Yoga on Birth Labor Duration and Pain

Table 3. Description of the primary study of the effect of prenatal yoga on labor duration

\begin{tabular}{|c|c|c|c|c|c|c|c|}
\hline $\begin{array}{l}\text { Author } \\
\text { (Year) }\end{array}$ & $\begin{array}{c}\text { Country } \\
\text { (Continent) }\end{array}$ & $\begin{array}{c}\text { Study } \\
\text { Design }\end{array}$ & Sample & $\mathbf{P}$ & $\mathbf{I}$ & C & $\mathbf{O}$ \\
\hline $\begin{array}{l}\text { Balantha- } \\
\text { kodi et al. } \\
\text { (2018) }\end{array}$ & $\begin{array}{l}\text { India } \\
\text { (Asia) }\end{array}$ & RCT & $\begin{array}{l}\text { Yoga Group: } 67 \\
\text { Control grup: } 58\end{array}$ & $\begin{array}{l}\text { Pregnant } \\
\text { Woman }\end{array}$ & $\begin{array}{l}\text { Prenatal } \\
\text { Yoga }\end{array}$ & $\begin{array}{l}\text { Without } \\
\text { prenatal } \\
\text { yoga }\end{array}$ & $\begin{array}{l}\text { Labor } \\
\text { duration }\end{array}$ \\
\hline $\begin{array}{l}\text { Chuntha- } \\
\text { rapat et al. } \\
\text { (2008) }\end{array}$ & $\begin{array}{l}\text { Thailand } \\
\text { (Asia) }\end{array}$ & RCT & $\begin{array}{l}\text { Yoga Group: } 33 \\
\text { Control grup: } 33\end{array}$ & $\begin{array}{l}\text { Pregnant } \\
\text { Woman }\end{array}$ & $\begin{array}{l}\text { Prenatal } \\
\text { Yoga }\end{array}$ & $\begin{array}{l}\text { Without } \\
\text { prenatal } \\
\text { yoga }\end{array}$ & $\begin{array}{l}\text { Labor } \\
\text { duration }\end{array}$ \\
\hline $\begin{array}{l}\text { Jahdiet al } \\
\text { (2016) }\end{array}$ & $\begin{array}{l}\text { Iran } \\
\text { (Asia) }\end{array}$ & RCT & $\begin{array}{l}\text { Yoga Group: } 30 \\
\text { Control grup: } 30\end{array}$ & $\begin{array}{l}\text { Pregnant } \\
\text { Woman }\end{array}$ & $\begin{array}{l}\text { Prenatal } \\
\text { Yoga }\end{array}$ & $\begin{array}{l}\text { Without } \\
\text { prenatal } \\
\text { yoga }\end{array}$ & $\begin{array}{l}\text { Labor } \\
\text { duration }\end{array}$ \\
\hline $\begin{array}{l}\text { Karnasih } \\
\text { (2018) }\end{array}$ & $\begin{array}{l}\text { Indonesia } \\
\text { (Asia) }\end{array}$ & RCT & $\begin{array}{l}\text { Yoga Group: } 11 \\
\text { Control grup: } 11\end{array}$ & $\begin{array}{l}\text { Pregnant } \\
\text { Woman }\end{array}$ & $\begin{array}{l}\text { Prenatal } \\
\text { Yoga }\end{array}$ & $\begin{array}{l}\text { Without } \\
\text { prenatal } \\
\text { yoga }\end{array}$ & $\begin{array}{l}\text { Labor } \\
\text { duration }\end{array}$ \\
\hline $\begin{array}{l}\text { Kumar et } \\
\text { al. (2017) }\end{array}$ & $\begin{array}{l}\text { India } \\
\text { (Asia) }\end{array}$ & RCT & $\begin{array}{l}\text { Yoga Group: } 40 \\
\text { Control grup: } 40\end{array}$ & $\begin{array}{l}\text { Pregnant } \\
\text { Woman }\end{array}$ & $\begin{array}{l}\text { Prenatal } \\
\text { Yoga }\end{array}$ & $\begin{array}{l}\text { Without } \\
\text { prenatal } \\
\text { yoga }\end{array}$ & $\begin{array}{l}\text { Labor } \\
\text { duration }\end{array}$ \\
\hline $\begin{array}{l}\text { Levettet al. } \\
\text { (2017) }\end{array}$ & $\begin{array}{l}\text { Australia } \\
\text { (Australia) }\end{array}$ & $\mathrm{RCT}$ & $\begin{array}{l}\text { Yoga Group: } 86 \\
\text { Control grup: } 83\end{array}$ & $\begin{array}{l}\text { Pregnant } \\
\text { Woman }\end{array}$ & $\begin{array}{l}\text { Prenatal } \\
\text { Yoga }\end{array}$ & $\begin{array}{l}\text { Without } \\
\text { prenatal } \\
\text { yoga }\end{array}$ & $\begin{array}{l}\text { Labor } \\
\text { duration }\end{array}$ \\
\hline $\begin{array}{l}\text { Mohyadin } \\
\text { (2019) }\end{array}$ & $\begin{array}{l}\text { Iran } \\
\text { (Asia) }\end{array}$ & RCT & $\begin{array}{l}\text { Yoga Group: } 11 \\
\text { Control grup: } 11\end{array}$ & $\begin{array}{l}\text { Pregnant } \\
\text { Woman }\end{array}$ & $\begin{array}{l}\text { Prenatal } \\
\text { Yoga }\end{array}$ & $\begin{array}{l}\text { Without } \\
\text { prenatal } \\
\text { yoga }\end{array}$ & $\begin{array}{l}\text { Labor } \\
\text { duration }\end{array}$ \\
\hline $\begin{array}{l}\text { Satyapriya } \\
(2013)\end{array}$ & $\begin{array}{l}\text { India } \\
\text { (Asia) }\end{array}$ & RCT & $\begin{array}{l}\text { Yoga Group: } 51 \\
\text { Control grup: } 45\end{array}$ & $\begin{array}{l}\text { Pregnant } \\
\text { Woman }\end{array}$ & $\begin{array}{l}\text { Prenatal } \\
\text { Yoga }\end{array}$ & $\begin{array}{l}\text { Without } \\
\text { prenatal } \\
\text { yoga }\end{array}$ & $\begin{array}{l}\text { Labor } \\
\text { duration }\end{array}$ \\
\hline $\begin{array}{l}\text { Yekefallah } \\
(2021)\end{array}$ & $\begin{array}{l}\text { Iran } \\
\text { (Asia) }\end{array}$ & RCT & $\begin{array}{l}\text { Yoga Group: } 67 \\
\text { Control grup: } 58\end{array}$ & $\begin{array}{l}\text { Pregnant } \\
\text { Woman }\end{array}$ & $\begin{array}{l}\text { Prenatal } \\
\text { Yoga }\end{array}$ & $\begin{array}{l}\text { Without } \\
\text { prenatal } \\
\text { yoga }\end{array}$ & $\begin{array}{l}\text { Labor } \\
\text { duration }\end{array}$ \\
\hline
\end{tabular}

Table 4. Description of the primary study of the effect of prenatal yoga on labor pain

\begin{tabular}{|c|c|c|c|c|c|c|c|}
\hline $\begin{array}{l}\text { Author } \\
\text { (Year) }\end{array}$ & $\begin{array}{c}\text { Country } \\
\text { (Continent) }\end{array}$ & $\begin{array}{c}\text { Study } \\
\text { Design }\end{array}$ & Sample & $\mathbf{P}$ & I & C & $\mathbf{O}$ \\
\hline $\begin{array}{l}\text { Balantha- } \\
\text { kodi et al. } \\
\text { (2018) }\end{array}$ & $\begin{array}{l}\text { India } \\
\text { (Asia) }\end{array}$ & RCT & $\begin{array}{l}\text { Yoga Group: } 67 \\
\text { Control grup: } 58\end{array}$ & $\begin{array}{l}\text { Pregnant } \\
\text { Woman }\end{array}$ & $\begin{array}{l}\text { Prenatal } \\
\text { Yoga }\end{array}$ & $\begin{array}{l}\text { Without } \\
\text { prenatal } \\
\text { yoga }\end{array}$ & $\begin{array}{l}\text { Labor } \\
\text { Pain }\end{array}$ \\
\hline $\begin{array}{l}\text { Chuntha- } \\
\text { rapat et al. } \\
\text { (2008) }\end{array}$ & $\begin{array}{l}\text { Thailand } \\
\text { (Asia) }\end{array}$ & RCT & $\begin{array}{l}\text { Yoga Group: } 33 \\
\text { Control grup: } 33\end{array}$ & $\begin{array}{l}\text { Pregnant } \\
\text { Woman }\end{array}$ & $\begin{array}{l}\text { Prenatal } \\
\text { Yoga }\end{array}$ & $\begin{array}{l}\text { Without } \\
\text { prenatal } \\
\text { yoga }\end{array}$ & $\begin{array}{l}\text { Labor } \\
\text { Pain }\end{array}$ \\
\hline $\begin{array}{l}\text { Jahdiet al. } \\
\text { (2016) }\end{array}$ & $\begin{array}{l}\text { Iran } \\
\text { (Asia) }\end{array}$ & $\mathrm{RCT}$ & $\begin{array}{l}\text { Yoga Group: } 30 \\
\text { Control grup: } 30\end{array}$ & $\begin{array}{l}\text { Pregnant } \\
\text { Woman }\end{array}$ & $\begin{array}{l}\text { Prenatal } \\
\text { Yoga }\end{array}$ & $\begin{array}{l}\text { Without } \\
\text { prenatal } \\
\text { yoga }\end{array}$ & $\begin{array}{l}\text { Labor } \\
\text { Pain }\end{array}$ \\
\hline $\begin{array}{l}\text { Karnasih } \\
(2018)\end{array}$ & $\begin{array}{l}\text { Indonesia } \\
\text { (Asia) }\end{array}$ & $\mathrm{RCT}$ & $\begin{array}{l}\text { Yoga Group: } 11 \\
\text { Control grup: } 11\end{array}$ & $\begin{array}{l}\text { Pregnant } \\
\text { Woman }\end{array}$ & $\begin{array}{l}\text { Prenatal } \\
\text { Yoga }\end{array}$ & $\begin{array}{l}\text { Without } \\
\text { prenatal } \\
\text { yoga }\end{array}$ & $\begin{array}{l}\text { Labor } \\
\text { Pain }\end{array}$ \\
\hline $\begin{array}{l}\text { Mohyadin } \\
\text { (2019) }\end{array}$ & $\begin{array}{l}\text { Iran } \\
\text { (Asia) }\end{array}$ & RCT & $\begin{array}{l}\text { Yoga Group: } 11 \\
\text { Control grup: } 11\end{array}$ & $\begin{array}{l}\text { Pregnant } \\
\text { Woman }\end{array}$ & $\begin{array}{l}\text { Prenatal } \\
\text { Yoga }\end{array}$ & $\begin{array}{l}\text { Without } \\
\text { prenatal } \\
\text { yoga }\end{array}$ & $\begin{array}{l}\text { Labor } \\
\text { Pain }\end{array}$ \\
\hline
\end{tabular}


Riawati et al./ The Effect of Prenatal Yoga on Birth Labor Duration and Pain

1. The effect of prenatal yoga on the labor duration

\section{a. Forest Plot}

Interpretation of the results of the metaanalysis process can be seen through the forest plot. Figure 2 shows that prenatal yoga practice 0.88 times reduced the duration of labor in pregnant women compared to without prenatal yoga and was statistically significant $(\mathrm{P}<0.001)$. The heterogeneity of the research data shows $\mathrm{I}^{2}=86 \%$ so that the distribution of the data is declared heterogeneous (random effect model).

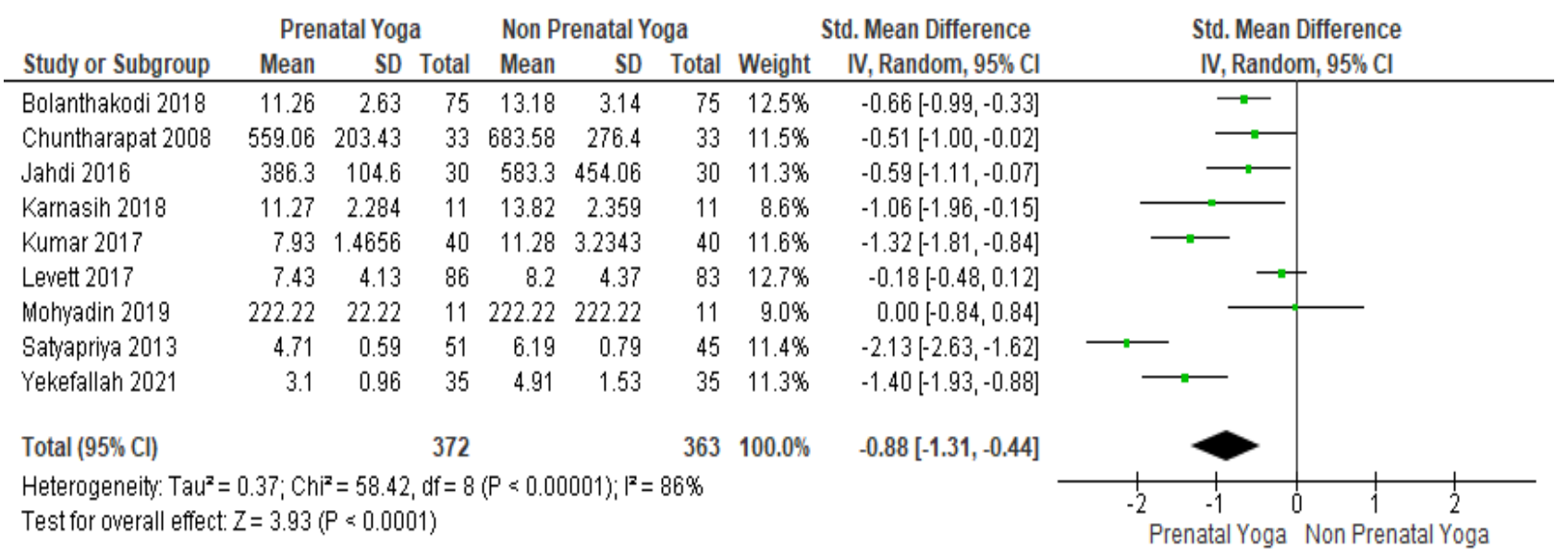

Figure 2. Forest Plot Effect of Prenatal Yoga to Labor Duration

\section{a. Funnel Plot}

Based on Figure 3 of the 9 articles analyzed, there is no publication bias which is indicated by the symmetrical distribution of the right and left plots where 5 plots are on

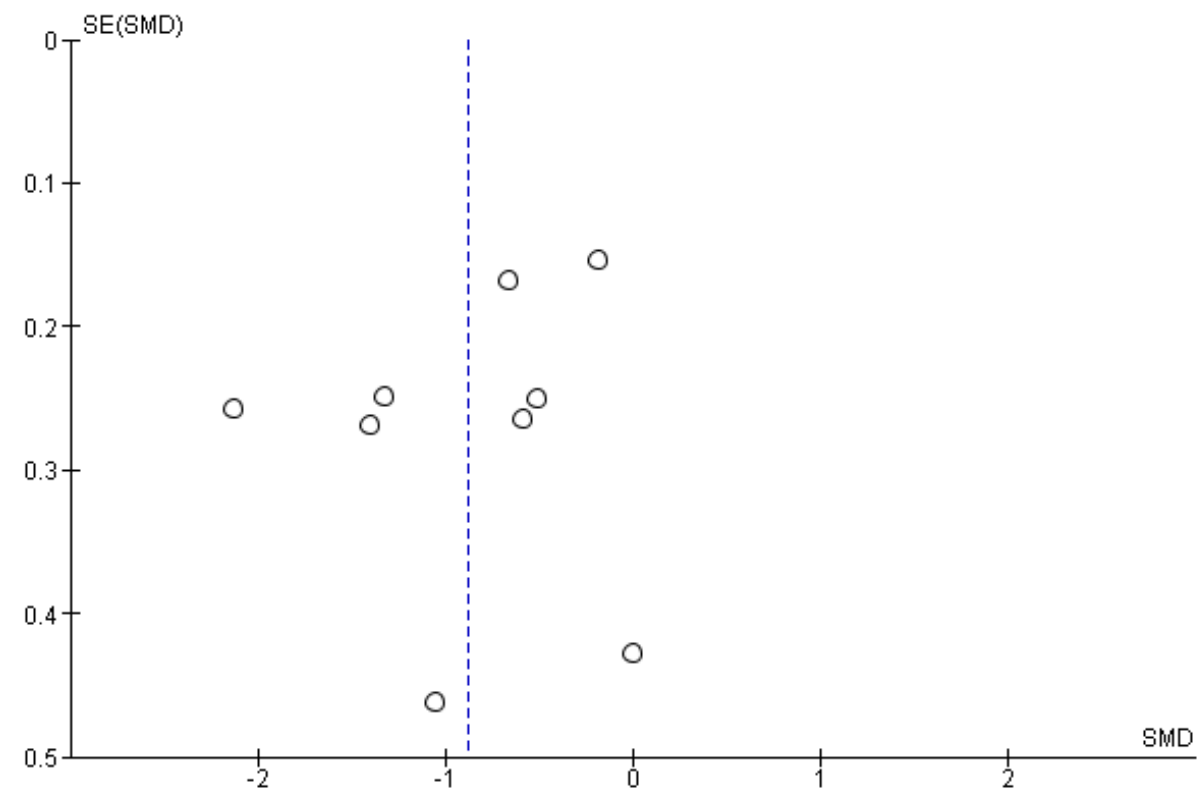

Figure 3. Funnel Plot Effect of Prenatal Yoga to Labor Duration the right and 4 plots are on the left. The plot on the left of the graph appears to have a standard error between 0.2 and 0.5 and the plot on the right has a standard error between 0.1 and 0.5 . 
Riawati et al./ The Effect of Prenatal Yoga on Birth Labor Duration and Pain

2. The Effect of Prenatal Yoga on Labor Pain

\section{a. Forest Plot}

Interpretation of the results of the metaanalysis process can be seen through the forest plot. Figure 4 shows that prenatal yoga practice 0.88 times reduced labor pain in pregnant women compared to no prenatal yoga and was statistically significant $(\mathrm{p}=0.002)$. The heterogeneity of the research data shows I $2=77 \%$ so that the distribution of the data is declared heterogeneous (random effect model).

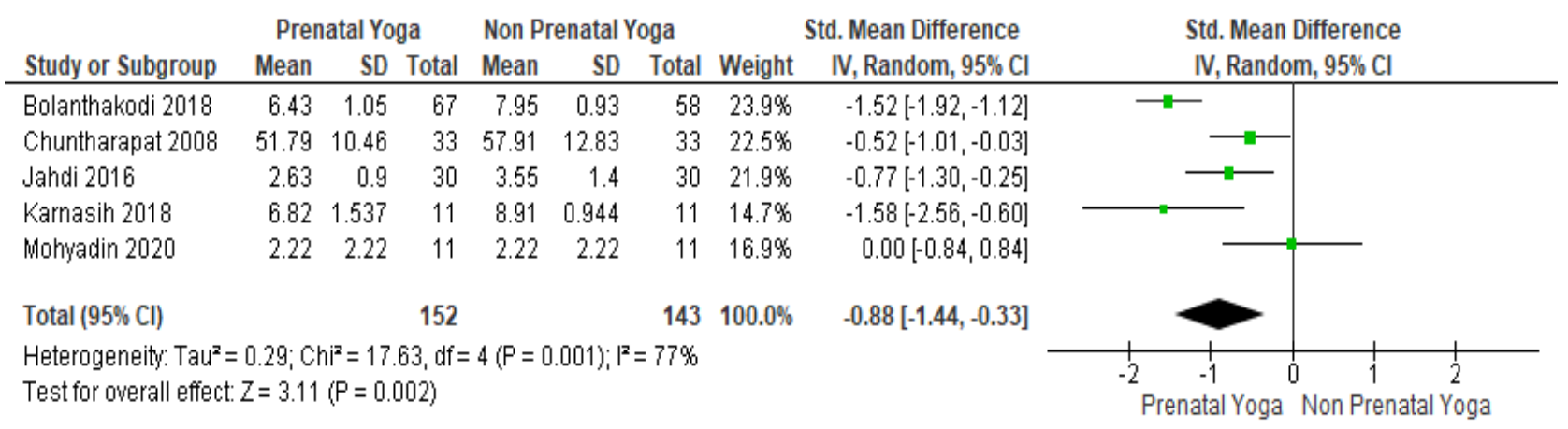

Figure 4. Forest plot effect of prenatal yoga on labor pain

\section{a. Funnel Plot}

Based on Figure 5, the funnel plot does not show any publication bias which is indicated by the symmetry of the right and left plots of the leaflets where 3 plots are on

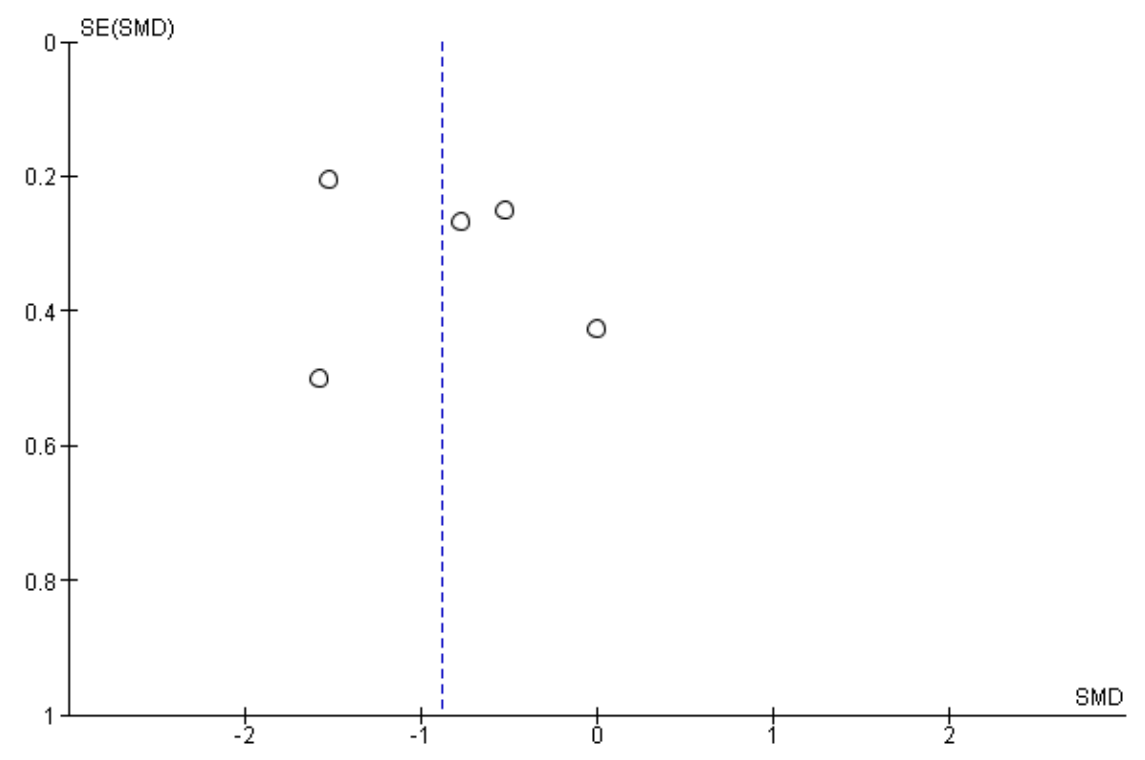

Figure 5. Funnel Plot Effect of Prenatal Yoga on Labor Pain

\section{DISCUSSION}

This systematic study and meta-analysis raised the theme of the effect of prenatal the right and 2 plots are on the left. The plot on the left of the graph appears to have a standard error between 0.2 and 0.6 and the plot on the right appears to have a standard error between 0.2 and o.6. yoga on labor duration and labor pain. The dependent variables analyzed were labor duration and labor pain. This meta-analysis 
study used a study that controlled the confounding factors. It can be seen from the inclusion criteria of the study, namely using a randomized controlled trial research design and the statistical results of each study include a standardized mean difference.

Estimates of the combined effect of prenatal yoga on labor duration and labor pain were processed using Revman 5.3 with the continuous difference method on bivariate data of two groups that had been controlled for confounding factors by randomization. The results of the systematic study and meta-analysis are presented in the form of forest plots and funnel plots.

The forest plot shows an overview of the information for each study examined in the meta-analysis, and estimates of the overall results (Murti, 2018).

Funnel Plot is a diagram in a metaanalysis that is used to demonstrate the possibility of publication bias. (Murti, 2018).

\section{The Effect of Prenatal Yoga on the Duration of Labor}

There are 9 research articles from various countries using the Randomized controlled trial method that can be used as a source of research for this meta-analysis. The forest plot results showed that prenatal yoga practice could reduce labor duration 0.88 times compared to no prenatal yoga $(\mathrm{SMD}=$ 0.88 ; 86\% CI -1.31 to $-0.44 \mathrm{p}<0.0001)$.

This is in line with Rong et al. (2020) which states that pregnant women who do prenatal yoga will have a shorter duration of labor compared to women who do not do prenatal yoga and it is statistically significant $(\mathrm{MD}=-120.78$; CI $95 \%=-166.33$ to $75.23 \mathrm{p}<0.001)$. This study is also in line with research conducted by Curtis et al., (2012) which stated that the duration of labor was significantly shorter in the yoga group than in the control group.
Yoga practice during pregnancy consists of several stages, namely: stages of pranayama, asanas, relaxation and meditation techniques. All of these stages will provide enormous benefits for the condition of the mother and fetus (Karnasih, 2018).

The stages of Pranayama (regular breathing manipulation) taught during prenatal yoga can be applied when the mother is in labor so that the mother feels relaxed. The existence of relaxation in the body can affect oxygen intake and ATP secretion for the uterine contraction process so that cervical opening becomes faster (Karnasih, 2018).

Asana techniques in prenatal yoga practice can help make the body more flexible and strengthen muscles at the same time. Relaxation techniques will help increase self-awareness, conserve energy, create a breathing rhythm during labor and relieve tension during contractions. Meditation will help to release tension, overcome stress and fear and will make the mind calm and centered on the body. With these techniques, labor will take place easily and the duration of labor will be shorter (Gupta et al., 2018).

\section{The Effect of Prenatal Yoga on Labor Pain}

There are 5 research articles from various countries using the Randomized controlled trial method that can be used as a source of meta-analysis research. The results of the forest plot show that prenatal yoga practice can reduce labor pain o.88 times compared to without doing prenatal yoga $(\mathrm{SMD}=$ $0.88 ; 77 \% \mathrm{CI}=-1.44$ to $-0.33 \mathrm{p}=0.002)$. This is in line with Jahdi et al. (2016) which stated that pregnant women in the control group had higher pain intensity than pregnant women in the experimental group (yoga) with a significance number of $\mathrm{p}=$ o.01. 
Kawanishi et al.(2015) who stated that yoga practice during pregnancy can reduce labor pain. Hawrelak et al. (2009) also stated that pregnant women who practice yoga for 30 minutes and do it 3 times a week can reduce pain during labor and shorten the duration of labor. Yoga practice is focused as an educational program and will be offered to every pregnant woman to reduce labor pain (Shim et al., 2012). The low labor pain in pregnant women who do prenatal yoga is because during yoga practice the emphasis is on correct breathing techniques, relaxation and meditation of the mother's body and mind, so that the mother is better able to overcome the pain she feels Controlled breathing technique taught during yoga is one of the nonpharmacological techniques that can help reduce pain perception (Marwa, 2017). Yoga is an invasive and non-pharmacological method that has been shown to increase strength and flexibility (Sun et al., 2010).

Regular practice of yoga has been shown to be beneficial for the mind and body because yoga can increase spinal flexibility, increase cerebrospinal fluid circulation and increase the release of endorphins and serotonin (Campbell et al., 2004). Yoga practice also serves to raise the threshold for pain perception during labor (Narendran et al., 2005).

Prenatal yoga exercises can strengthen and increase the flexibility of the perineum, vagina and sphincter muscles so as to facilitate normal labor and delivery. Prenatal yoga practice can also lead to lower labor induction rates, shorter labor durations and lower pain perception (Dykema et al., 2011).

\section{AUTHOR CONTRIBUTION}

Meida Siwi Riawati is the main researcher who selects the topic, searches and collects research data. Uki Retno Budihastuti and Hanung Prasetya played a role in analyzing data and reviewing research documents, analyzing data and reviewing research documents.

\section{FUNDING AND SPONSORSHIP}

This study is self-funded.

\section{CONFLICT OF INTEREST}

There is no conflict of interest in this study.

\section{ACKNOWLEDGEMENT}

We are very grateful to database providers PubMed, Science Direct, Springer Link, and Google Scholar.

\section{REFERENCE}

Aflahiyah S, Tamtomo DG, Prasetya H (2020). Effectiveness of prenatal yoga on sleep quality and reduction of anxiety during pregnancy: A Meta Analysis. Matern Child Health J. 5(6): 629-640. doi: 10.26911/thejmch.2020.05.06.03

Balanthakodi C, Raghunandan C, Saili A, Mondal S, Saxena P (2018). Prenatal Yoga: Effect on alleviation of labor pain and birth outcome. J Altern Complement Med.24 (12): 1181-1188. doi: 10.1089/acm.2018.0079

Bussing A, Khalsa SB, Michalsen A, Sherman KJ, Telles $S$ (2012). Yoga as a therapeutic intervention. Evid Based Complementary Altern. Med.2012: 1. doi: 10.1155/2012/174291.

Campbell D, Moore K. (2004). Yoga as a preventative and treatment for depression, anxiety, and stress.Int $\mathrm{J}$ Yoga Therap. 14(1): 53-58. doi: https://doi.org/10.17761/ijyt.14.1.t74 27823p2478255.

CEBMa(2014). Critical appraisal. Available at: http://cebma.org/resources-and- 
Riawati et al./ The Effect of Prenatal Yoga on Birth Labor Duration and Pain

tools/what-iscritical-appraisal/

Accesed: 21 Februari 2021.

Chuntharapat S, Petpichetchian W, Hatthakit U (2008). Yoga during pregnancy: effects on maternal comfort, labor pain and birth outcomes.Complement Ther Clin Pract. 14(2): 105-115. doi: 10.1016/j.ctcp.2007.12.007.

Curtis K, Weinrib A, Katz J (2012). Systematic review of yoga for pregnant women: current status and future directions. Evid Based Complementary Altern Med. 2012:. 13 doi: 10.1155/2012/715942.

Dykema R (2011) Yoga for fitness and wellness, 2nd ed.; Cengage Learning: Boston, MA, USA,

Gupta A, Janu N, Punia R (2018). Eficacy of yoga and anupreksha in natural birthing and reducing labor duration.Saudi J Humanities Soc Sci. 23(4): 65-67. doi: 10.9790/0837-2304026567

Irianti B, Halida EM, Duhita F (2014). Asuhan kehamilan berbasis bukti (Evidence-based maternity care): jakarta:sagung seto

Jahdi F., Sheikhan F, Haghani H, Sharifi B, Ghaseminejad A, Khodarahmian M, Rouhana N (2017). Yoga during pregnancy: the effects on labor pain and delivery outcomes (a randomized controlled trial).Complement Ther Clin Pract 27: 1-4. doi: 10.1016/j.ctcp.2016.12.002.

Hawrelak J, Myers S (2009). Yoga in pregnancy. J Tradit Complement Med. 8(2):59-60. doi: 10.1097/GRF.ooo0000000000210

Karnasih I (2018). The effect of yoga towards birth delivery output. IJSTR. 7(12): 62-66.

Kawanishi Y, Hanley SJ, Tabata K, NakagiY, Ito T, Yoshioka E, Yoshida T, Saijo Y (2015). Effect of prenatal yoga: a systematic review of randomized controlled trials. JapJ Public Health. 62(5): 221-31. doi: 10.11236/jph62.5_221

Kumar A, Chandrakar R. (2017). A study on the effect of integrated yoga on labor pain. Int J Yoga Allied Sci. 6(1):13-21.

Levvet KM, Smith CA, Bensoussan A, Dahlen HG (2017). Complementary therapies for a labour and birth study: a randomized controlled trial of antenatal integrative for pain management in labour.BMJ Open. 1-10. doi: 10.1136/bmjopen-2015-010691.

Mohyadin E, Ghorashi Z, Molamomanaei Z. (2020). The effect of practicing yoga during pregnancy on labor stages leght, anxiety and pain: a randomized controlled trial.Int J Yoga Allied Sci.15. doi: http://doi.org/10.1515/jcim2019-0291

Murti, B. (2018). Prinsip dan metode riset epidemiologi. Surakarta: Program Studi Ilmu Kesehatan Masyarakat, Program Pascasarjana, Universitas Sebelas Maret.

Narendran S, Nagarathna R, Narendran V, Gunusheela S, Nagendra HRR (2005). Efficacy of yoga on pregnancy outcome. J Complement Integr Med. 11(2): 237-244. doi: 10.1089/acm.2005.11.237.

Rong L, Dai LJ, Ouyang YQ (2020). The effectiveness of prenatal yoga on delivery outcomes: a meta-analysis. Complement Ther Clin Pract. 39: 101157. doi: 10.1016/j.ctcp.2020.101157.

Satyapriya M, Raghuram N, Venkatram P, Ramarao NH (2013). The effect of integraded yoga on labor outcome: a randomized controlled study. Inter $\mathrm{J}$ Birth. 3(3). doi: 10.1891/2156-5287$.3 \cdot 3.165$

Shim CS, Lee YS. effects of a yoga-focused prenatal program on stress, anxiety, 
Riawati et al./ The Effect of Prenatal Yoga on Birth Labor Duration and Pain

self confidence and labor pain in pregnant women with in vitro fertilization treatment.J Korean Acad Nurs. 42(3): 369-76.doi:10.4040/jkan.2012.42.3.369

Sun YC, Hung, YC, Chang Y, Kuo SC (2010). Effects of a prenatal yoga programme on the discomforts of pregnancy and maternal childbirth self-efficacy in taiwan.J Midwifery. 26(2010)e31-e36. doi: 10.1016/j.midw.2009.01.005

Yekefallah L, Namdar P, Dehghankar L, Golestaneh F, Taheri S, Mohammadkhaniha F (2021). The effect of yoga on the delivery and neonatal outcomes in nulliparous pregnant women in iran: a clinical trial study.J Res Square.2-15. doi: http://doi.org/10.21203/rs.3.rs-1. 